\title{
An Actor's Process in Performing the Role of Oberon in William Shakespeare's "A Midsummer Night's Dream"
}

Kyle Walter

Follow this and additional works at: https://researchrepository.wvu.edu/etd

\section{Recommended Citation}

Walter, Kyle, "An Actor's Process in Performing the Role of Oberon in William Shakespeare's "A Midsummer Night's Dream"'" (2015). Graduate Theses, Dissertations, and Problem Reports. 6894. https://researchrepository.wvu.edu/etd/6894

This Thesis is protected by copyright and/or related rights. It has been brought to you by the The Research Repository @ WVU with permission from the rights-holder(s). You are free to use this Thesis in any way that is permitted by the copyright and related rights legislation that applies to your use. For other uses you must obtain permission from the rights-holder(s) directly, unless additional rights are indicated by a Creative Commons license in the record and/ or on the work itself. This Thesis has been accepted for inclusion in WVU Graduate Theses, Dissertations, and Problem Reports collection by an authorized administrator of The Research Repository @ WVU. For more information, please contact researchrepository@mail.wvu.edu. 
An Actor's Process in Performing the Role of Oberon in William Shakespeare's $A$ Midsummer Night's Dream

\author{
Kyle Walter \\ Thesis submitted to the College of Creative Arts \\ West Virginia University \\ in partial fulfillment of the requirements \\ for the degree of \\ Master of Fine Arts in Acting
}

Gerald McGonigle, MFA, Professor/Head of Graduate Acting, Chair Leland Blair, MFA, Assistant Professor

Jessica Morgan Bishop, MFA, Associate Professor

School of Theatre and Dance

Morgantown, West Virginia

2015

Keywords: Acting, Shakespeare, Oberon, Midsummer Night's Dream 


\section{How Now Spirit? - Abstract}

\section{An Actor's Process in Performing the Role of Oberon in William Shakespeare's A Midsummer Night's Dream}

\section{Kyle Walter}

I was actually fortunate enough to choose the role I could use to write my thesis on during my last year of graduate school here at West Virginia University. I played the role of Martin in Theresa Rebeck's Seminar in the production of the WVU School of Theatre and Dance season; however I chose to use Oberon for multiple reasons.

I was originally going to use both roles and write a sort of compare and contrast document. I realize that would have been a "Midsummer Nightmare." So this decision led me here, taking on Oberon. I wanted to attempt to put aside any preconceived notions of the role or the play for that matter, and work from the ground up. A truthful, fresh look at one of theatre's most classic comedies was needed for this particular experience. In this complete evaluation, I will expand on my experience going through the journey of taking the role from black and white words on the page to a living, breathing human being, or king of the fairies rather, and how the approach weaved and wound from the read through to closing night; all while getting a chance to work with my MFA head. Only time and the following pages will tell the story of A to Z, and all the letters in between. 
According to the Scrip- Table of Contents

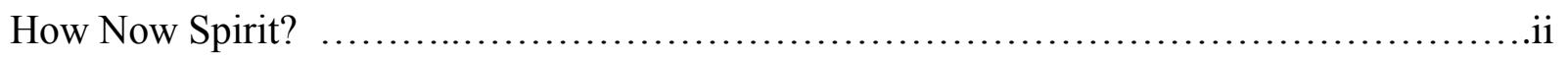

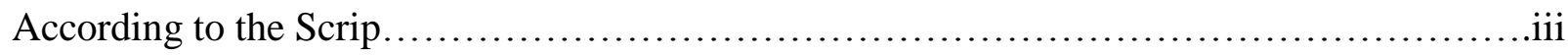

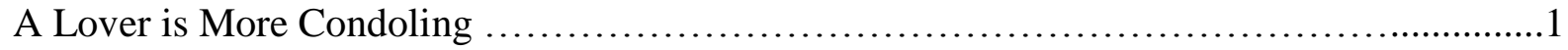

A Very Good Piece of Work, I Assure You.............................................

Have You the Lion's Part Written? .................................................

That Will Ask Some Tears in the True Performing of It ...............................20

I Pray You; For Your Play Needs No Excuse. . ...................................... 31

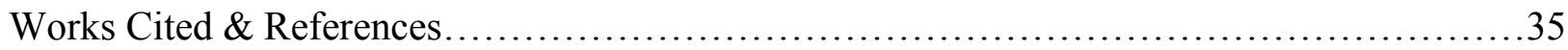




\section{Introduction - A Lover is More Condoling}

My journey that brought me to theatre is an interesting one. I was a hot head high school athlete, playing baseball and basketball with every intention of following through on a life of sports and athletics. However, after a change of heart, I found myself backstage of my high school theatre helping hang lights with a friend from the wrestling team who did this in his free time. I remember feeling at home with this group of people in this environment; staying at school late and problem solving in a group effort. The department was doing a production of Fools by Neil Simon. The second I saw a run of this show, I knew I could do this forever. The comedy and fast-paced atmosphere was absolutely gripping. From then on, I was invested in learning more about this crazy craft of acting.

I studied theatre at East Tennessee State University in Johnson City, Tennessee before coming to WVU for my graduate work. While at ETSU, coincidentally enough, we $\operatorname{did} A$ Midsummer Night's Dream my junior year and I was very excited to audition. I had been in Hamlet as well as As You Like It in the two previous years there, so I felt ready and well versed (enough) to sink my teeth into this well-known comedy of Shakespeare's. I very much wanted to play the role of Nick Bottom. I felt the clownish, buffoonish, ham nature of the leader of the rude mechanicals would have suited me very well, and at the time, I'm sure it would have. Nonetheless I ended up being cast as Francis Flute, the bellows mender, which was a fun role in itself. And of course getting to milk the Pyramus and Thisbe scene for all it was worth was indescribably fun.

To come back to WVU, after being placed in the role of Oberon, I was nervous and anxious to tackle this kingly character. So much of my time here in the program has been 
dedicated to trust. Trust is needed between my scene partners and me, and really talking and listening in the world of Sanford Meisner. This work requires and produces genuine and authentic communication between players. The more and more I delved into the program, I knew that trust was going to be the absolute cornerstone. Before this production, I knew that I was yearning for this type of character to put what I had been learning to the test. I loved being able to encounter this role at the end of my Meisner training here because it was an exploration and exemplification of that trust as well as the stillness, power, and control that goes into a role like Oberon. Allow me to take a closer examination of these stage principles in this journey. 


\section{Plot Synopsis - A Very Good Piece of Work, I Assure You}

William Shakespeare's A Midsummer Night's Dream opens with a furious Egeus storming into the Duke Theseus' quarters, who is in the middle of a quarrel with his wife, the queen Hyppolita (which might very well lead to parallel that of Titania and Oberon). Egeus is very upset about the fact that his daughter Hermia is determined to be wed to Lysander. However, Demetrius, another Athenian youth, sees himself to be most fit to Hermia. Hermia bursts into hysterics as no one will seem to grant her wishes and desires. Theseus, Egeus, and Demetrius depart from the court, leaving Lysander and Hermia to plan out a secret meeting deep in the woods, at the house of Lysander's aunt. Upon this discussion, the fourth young lover is introduced: Helena. She wallows into the scene, quite miffed about her love for Demetrius and how it is quite the one way street of the heart. Lysander and Hermia run off in hopes of eloping, reassuring Helena that it will all work out in the end.

In the next chunk of the story, we are introduced to infamous rude mechanicals, who have been taken on the task of performing a play for the royal court on the wedding day of Duke Theseus and Hippolyta. They are hoping to be selected to perform their play, and thrive as a cinderella story of sorts. They are going to rehearse The Most Lamentable Comedy and Most Cruel Death of Pyramus and Thisbe. In short, they are six rag-tag working class fellows in town. They are quite unintelligent and uneducated which naturally will cause hilarity to ensue. They cast the play, and Peter Quince demands they begin rehearsing the play in the woods at night, so as not to be seen by the public.

Following the mechanicals, we finally get introduced to the world of the mystical. One of the play's driving forces is revealed in the form of Puck. Puck is somewhat of the forest jester, 
working for Oberon, the king of the fairies. "I jest to Oberon and make him smile," as Puck says to a passing fairy. Throughout this scene, we become aware of the rest of the play's exposition. It is revealed that Oberon and his wife Titania, the queen of the fairies, are in a quarrel over the ownership of a young Indian boy in the woods. The argument between Oberon and Titania is one of forcible nature and raging jealousy, ending with Titania storming off and instructing Oberon to not come back near her or her bed chamber. This infuriates Oberon to one of the play's first motions. He summons Puck to fetch a flower with magical potions, absorbed by Cupid's falling arrow. He says the powers will make anyone fall in love with the very next thing he or she lays eyes on.

Our next visual piece of action comes in the form of Helena writhing on stage in desperate hopes of finding her beloved Demetrius, who eventually runs into her, much to his annoyance. He rejects once again, exclaiming how he will never love her, how she makes him sick, and actually threatens her with the idea of hypothetical rape; seeing how she has stranded herself alone in the dark woods. Demetrius finally breaks her hold and runs out deeper into the woods in search of his love Hermia. Following this squabble, is the return of Puck with the flower and Oberon promptly lays it in the eyes of Titania, who is deeply asleep from her fairies singing her a lullaby. He commands the unconscious queen to fall madly in love with whomever, or whatever strikes her next.

Shortly after, Puck returns to follow through on his next task, which was to put the poisonous flower in the eye of Demetrius so he would fall in love with Helena. But of course, he fails spectacularly at said task and drops it into the eyes of Lysander. Naturally, in this farcical world, he awakes and immediately lays his eyes on Helena. Thus begins the four lovers tripping and traipsing their way through the tangled web of confusion. Moving through the story, Puck 
happens on the rehearsal of the rude mechanicals and finds Nick Bottom, who is playing Pyramus, and turns his head into that of a donkey. At this point, Titania has arisen from her sleep and is struck with the sight of the "angel" that has woken her from her flowery bed. Her fairies run quickly by his side, as they ordered by the queen to tend to his every need and desire.

The ecstatic Puck whisks in to weave the tale of his doings to his master Oberon, who is momentarily thrilled with the fact that his wife is enthralled with a donkey. However, this joy is quickly replaced with outrage. Upon the entrance of the lovers, Oberon discovers that Puck has poisoned the wrong one, and now the foursome is in complete love allegiance reversal and in a state of teen age angst-driven hysterics. As the two forest dwellers watch the madness unfold, Oberon presents Puck with the remedy flower that will undo the deed and set things back to the way they should be. But of course, the foolish Puck mistakes the lovers yet again and now has only driven them further into despondency. The quadrilateral kids have an all-out screaming match and threaten one another on multiple counts of betrayal and broken promises. Finally, one by one, they all march off to the beats of their own drums. Oberon, still in disbelief of Puck's sheer stupidity, gives him one final order to straighten out the mess. Using his voice as a disguise, Puck feigns fighting words and leads the lads on an exhausting chase and eventually tires Lysander and Demetrius out, bringing them to sleep, so he can finally right the ship.

Inching closer to tying things up, Oberon decides he has had enough of torturing Titania, and drops the remedy into her eye while she is asleep. Upon her waking she explains how she dreamt of loving an ass, who is coincidentally asleep next to her. Oberon explains the events and hurries her off to the court. Theseus and Egeus re-enter to find the young ones asleep on the ground, and they sort out their love connections to one another and happily, yet a bit confusedly, make their way home. 
Finally, in the end of the play, we see the mechanicals, who have been ever so hard at work, perform their play for all of the members of the court. The play within the play the most ridiculous thing that anyone has ever seen. The mechanicals play their moments to the extreme and give the audience a good story and some whole-hearted laughter. The Duke stops the play prematurely before the epilogue, but allows the players to do their Bergomask dance as they exit the court. Oberon and Titania make one final appearance in the court to bless the house in all its rooms and for all its occupants. In the well rounded nature of the play, all the strings get tied up into perfect, warm knots. 


\section{Analysis - Have You the Lion's Part Written?}

With the setting of the world of the play and the happenings within it laid out, the scope becomes now a bit more magnified on the character of Oberon, and my way into him. In An Actor Prepares, Constantine Stanislavski states, "There is no such thing as actuality on stage. Art is a product of the imagination, as the work of a dramatist should be. The aim of the actor should be to use his technique to turn the play into a theatrical reality. In this process, imagination plays by far the greatest part." A Midsummer Night's Dream led me to an endless possibility of imagination. The play is so fantastical that it does seem like a limitless task conjuring up the world, the body, and the voice of such a character under such circumstances. In my case, I was coming straight out of the process for Seminar in which I was a very realistic person in a very realistic world with very realistic interactions. Coming into this magical world of Oberon, it was quite the change of gears. However, as an actor, I recognized over time the similarities between the two settings, and really between any roles of any plays. Both of these characters are simply after something, with obstacles in their way. The only difference is the circumstances in which they have to do so.

I was genuinely excited to take on Oberon from day one and knew how much work it would be to create such a larger than life figure in a larger than life scenario. One of the first things to do with the story is recognize Oberon's series of events. Tracking one character's timeline is a useful way of clarifying the arch of the character, as well as the point of view of the character.

Oberon is first introduced in Act 2, Scene 1. Immediately the fight begins to break out between Oberon and his wife Titania. From atop the mystical tree, Oberon barks, 
"How canst thou thus, for shame, Titania

Glance at my credit with Hippolyta,

Knowing I know thy love to Theseus?

Didst thou not lead him through the glimmering night

From Perigenia, whom he ravished?

And make him with fair Aegles break his faith,

With Ariadne, and Antiopa? “ 1

Here, the jealousy is rearing its head as it is heard that these two royal members of the forest are duking it out in their first interaction. They are accusing each other of having affair after affair with other people including members of the court. Titania goes on to explain how their fighting and jealousy is disturbing the ways of nature. Oberon is simply demanding that he can have possession of the young Indian changeling boy to do his biddings around the forest, in addition to the one he already has. After continuing to deny him of his wish, Titania storms off with her gaggle of fairies.

I find it interesting and a bit baffling that such a small discrepancy causes all of the plays' main action to tumble forward. It is a simple gesture that Oberon is after; it is just the boy that he wants. However, this simplicity is magnified one hundred fold; he will not rest until he can win. Once I could let go of "why" it mattered so much and just live in the "what" Oberon is going to do about it, it made more sense to trust the situation and do whatever is necessary to get back at her. I had to reduce it because while it is a singular simple goal, it means everything to Oberon to win.

In all the frustration, Oberon calls Puck to his side and after recalling a memory, explains a task he must complete,

\footnotetext{
${ }^{1}$ All text is pulled from the Pelican Shakespeare edition of $A$ Midsummer Night's Dream.
} 
"That very time I saw (but thou coudst not)

Flying between the cold moon and the earth

Cupid, all armed. A certain he took

At a vair vestal, throned by the west,

And loosed his love shaft smartly from his bow,

As it should pierce a hundred thousand hearts.

But I might see young Cupid's fiery shaft

Quenched in the chaste beams of the wat'ry moon,

And the imperial vot'ress passed on,

In maiden meditation, fancy-free.

Yet marked I where the bolt of Cupid fell.

It fell upon a little western flower,

Before milk-white, now purple with love's wound,

And maidens call it love-in-idleness.

Fetch me that flower; the herb I showed thee once.

The juice of it, on sleeping eyelids laid,

Will make or man or woman madly dote

Upon the next live creature that is sees.

Fetch me this herb, and be thou here again

Ere the leviathan can swim a league."

After instructing this to Puck, he goes on to inform the audience of the powers to come,

"Having once this juice,

I'll watch Titania while she is asleep

And drop the liquor of it in her eyes.

The next thing then she, waking, looks upon

(Be it on lion, bear, or wolf, or bull, 
On medling monkey, or on busy ape)

She shall pursue it with the soul of love.

And ere I take this charm from off her sight

(as I can take it with another herb)

I'll make her render up her page to me.

But who comes here? I am invisible, And I will overhear their conference.”

With all of this, Oberon uses the language to illustrate this memory to Puck. All of Oberon's speech in this scene stays structurally within iambic pentameter, ten syllables per line. Also in this text, Oberon establishes the ever so important history of the flower and why it contains such an element of magic and control, paralleling his aspects in relation to the forest as well. This command sends Puck off to track down the magical flower and drives into the next moment of Demetrius trying to evade Helena throughout the woods while she desperately tries to trace him. During all of this Oberon is left on stage but invisible to watch the action unfold. When Demetrius is finally able to evade Helena and break out into other parts of the woods, Puck reenters with possession of the mystical flower he was ordered to find. Oberon proceeds to give further instruction by giving one of the plays most colorful speeches:

"I know a bank where the wild thyme blows,

Where oxlips and nodding violet grows,

Quite overcanopied with luscious woodbine,

With sweet musk roses, and with eglantine.

There sleeps Titania sometime of the night,

Lulled in these flowers with dances and delight;

And there the snake throws her enameled skin, 
Weed wide enough to wrap a fairy in.

And with the juice of this I'll streak her eyes

And make her full of hateful fantasies.

Take thou some of it and seek through this grove.

A sweet Athenian lady is on love

With a disdainful youth. Annoint his eyes;

But do it when the next thing he espies

May be the lady. Thou shalt know the man

By the Athenian garments he hath on.

Effect it with some care, that he may prove

More fond on her than she upon her love;

And look thou meet me ere the first cock crow."

One of the most challenging things that most come across when delving into Shakespeare is the language. Upon first look at a run like this it can seem long and overwhelming. The key is to find the hard stops, the periods, question marks and exclamation points. What are the complete thoughts? Then what are the parentheticals? Dealing with iambic pentameter means basically that I have a full line of text that has ten syllables within it. It is complex to a point following the lines of actual text versus following the complete thoughts. In such a poetic piece, it is crucial to discover the core sentences and questions then discover what all the extra fluffy stuff is that surrounds it and rounds it out. In this particular monologue for example, Oberon states that he knows where to find Titania, what he is going to accomplish with her, and telling Puck to do the same thing to Demetrius.

In the following scene, Oberon is successful in his quest and manages to drop the liquor of the flower into Titania's eyes. 
"What thou seest when thou dost wake,

Do it for thy true love take;

Love and languish for his sake.

Be it ounce or cat or bear,

Pard or boar with bristled hair,

In thy eye that shall appear

When thou wak'st, it is thy dear.

Wake when some vile thing is near."

Here we have a bit of a shift in the rhythm of the text. It has gone from iambic pentameter (being ten syllables for every line) to a beat of only seven syllables for every line of text. What this gives off is a sense of a lullaby feel rather than a mathematical one. This runs common throughout the course of the play when characters like Oberon and Puck are putting others under the spell of the potion. This change adds to the magical nature of the play and thus pursues a different attack in the language. Even today, hundreds of years later, we recognize that Shakespeare was doing this to give his actors a sense of tone and choice within the text much like in a musical theatre score. There is a rest here for a reason or a crescendo there for another. These are clues for the performers.

From this point in the story, all of Oberon's plot points are laid out to take place, and he does not come back into the action until Act 3, Scene 2. The mechanicals are hard at work with their play, Titania is asleep, and the lovers are deep within their adolescent confusion. Oberon makes the opening appearance in wonderment of his wife and what insane thing she has looked upon and fallen madly in love with. Quite immediately, he is greeted by Puck who is seemingly overjoyed with news. He bursts at the seams to elaborate to Oberon how he turned Nick 
Bottom's head into that of a donkey which terrifies his colleagues to the point of scattering away in the woods. Quickly after, he reveals that Nick Bottom is the very next thing that stumbled into Titania's vision and now she is in love with an ass!

Naturally, Oberon is thrilled and the two share a moment of joy and excitement. This is quickly stripped away upon the entrance of Hermia and Demetrius. Here it is realized that Puck has laid the love juice on the wrong fellow and now everything is backwards. Demetrius and Hermia fight for a few moments and eventually make their ways off and to sleep. In a moment of outrage and disappointment, Oberon says:

"What hast thou done? Thou hast mistaken quite And laid the love juice on some true love's sight.

Of thy misprision must perforce ensue

Some true love turned, and not a false turned true....

About the wood, go swifter than the wind,

And Helena of Athens, look thou find.

All fancy-sick she is, and pale of cheer

With sighs of love which costs the fresh blood dear.

By some illusion see thou bring her here.

I'll charm his eyes against she do appear."

Giving Puck yet another instruction on how to fix this quickly expanding debacle, Oberon sends him off in search of Helena. After Puck scurries off to attempt rectifying his mistake, Oberon then drops the flower power into the eyes of Demetrius. This, of course leads into the long scene with the lovers where Lysander and Demetrius are both seemingly in love with Helena. This drives Hermia into quite the hissy fit and she threatens to fight with Helena, which the boys are already doing with each other. Puck and Oberon sit idly by, invisible, 
watching this train wreck of a situation unfold, not to mention that everyone is playing against time, as the sun will be rising soon.

With one last attempt to make things right, Oberon scolds Puck in another long train of text:

"Thou seest these lovers seek a place to fight.

Hie, therefor robin, overcast the night.

The starry welkin cover thou anon

With drooping fog as black as Acheron,

And lead these testy rivals so astray

As one come not within another's way.

Like to Lysander sometime frame thy tongue,

And stir Demetrius up with bitter wrong,

And sometime rail thou like Demetrius.

And from each other look thou lead them thus

Till o'er their brows death-counterfeiting sleep

With leaden legs and batty wings doth creep.

Then crush this herb into Lysander's eye,

Whose liquor hath this virtuous property,

To take from thence all error with his might

And make his eyeballs roll with wonted sight.

When they next awake, all this derision

Shall seem a dream and fruitless vision,

And back to Athens shall the lovers wend

With league whos date til death shall never end.

Whiles I in this affair do thee employ,

I'll to my queen and beg her Indian boy; 
And then I will her charmed eye release

From monster's view, and all things shall be peace."

Once again, breaking it down into the individual ideas is crucial, to keep the simplicity and specificity of what the core message is. It makes long passages much easier to track into beats. Eight; there are eight complete thoughts with periods in this piece. That is the basis of what to go off of, and then how the rest weaves in and around those six full ideas. Basically, the lemans thoughts are as follows:

- The lovers are fighting.

- Make the night darker.

- Get the lovers lost in mist and fog to lead them astray from each other.

- Pretend to be Demetrius and Lysander using your voice, and egg them on.

- Tire them out until they are asleep.

- Drop the remedy in Lysander's eye, so he will go back to normal.

- When they wake up, it will seem like a dream to all of them.

- I'll get the boy from Titania, then give her the remedy as well. Then everything will be fine.

This is about as simple as I can make it for myself, but it does make quite the difference to see the ideas in a form like this, rather than amidst twenty-four lines of text in the script over the span of two pages. By doing this, I can focus more clearly on what exactly is being said. Then from this point, I figure out the words and how the meter fits in the moment of the scene. 
Moving forward, Puck accomplished this by getting all the lovers stone cold asleep on the ground, as well as Titania with her beloved Bottom. Oberon slowly and confidently enters this peaceful scene, seeing all six of them asleep on the ground, and once again feels back in control, backed up by:

"Welcome, good Robin. Seest thou this sweet sight?

Her dotage now do I begin to pity,

For meeting her of late behind the wood, Seeking sweet favors for this hateful fool, I did upbraid her and fall out with her.

For she his hairy temples then had rounded With coronet of fresh and fragrant flowers; And that same dew which sometime on the buds Was wont to swell, like round and orient pearls, Stood now within the pretty flowerets' eyes Like tears that did their own disgrace bewail. When I had at my pleasure taunted her, And she in mild terms begged my patience, I then did ask of her her changeling child;

Which straight she gave me, and her fairy sent

To bear him to my bower in fairy land.

And now I have the boy, I will undo

This hateful imperfection of her eyes. And, gentle Puck, take the transformed scalp From off the head of this Athenian swain; That, he awaking when the other do, May all to Athens back again repair, 
And think no more of this night's accidents

But as the fierce vexation of a dream.

But first I will release the fairy Queen.

Be as thou wast wont to be;

See as thou wast wont to see.

Dian's bud o'er Cupid's flower

Hath such force and blessed power.

Now, my Titania, wake you, my sweet Queen."

This is one of my absolute favorite pieces of text from the entire show. In addition to breaking it down for all its ideas and values, it is just such a different tone and pace for Oberon. From the moment his character is introduced, he is guns blazing and always working very hastily. He is rooted in revenge and resentment. But here, in the moments of finally settling down into what he has been after, it's a moment of catching his breath and slowing down. Upon the end of this speech, Oberon supplies Titania's eyes with the much-needed remedy of the spell, and then whisks her away to the court, but not after a quick comical moment of Titania waking next to her ass of a lover.

Oberon and Titania make their way to the wedding of Theseus and Hippolyta, where all the lovers have reconvened and melted into the arms of the ones they are supposed to be with. After the ridiculous showing of the mechanicals' performance of the play, Oberon, while hand in hand with his wife, gives a final blessing to the house and everyone in it.

From the text, there were clearly words that I, the actor, needed to look up. The definitions and pronunciations were carved from David and Ben Crystal's Shakespeare's Words. 


\section{○ $\quad$ ACT 2 SCENE 1}

- Tarry - Stay, wait for.

- Wonton - Promiscuous Woman.

- Perigenia - Egeus' Mistress

- Ravished - Abducted, carried by force.

- Henchman - Square, Page of Honor

- Promontory - A high point of land or rock projecting into a body of water.

- Dulcet - Sweet, mild, pleasant, agreeable.

- Vestal - Virgin, vowed to chastity.

- Chaste - Celibate, single, unmarried, pure.

- Imperial - Commanding, authoritative, unquestioned.

- Vot'ress - Woman under vow, devotee.

- Ere - Before (rather than)

- Leviathan - Sea-monster, whale.

- Render-Give up, surrender, yield.

- Nymph - Beauty, damsel, siren.

- Oxlips - Eurasian primula, usually having yellow flowers.

- Eglantine - Sweet brier

$$
\text { - ACT } 3 \text { SCENE } 2
$$

- Espy - Catch sight of, discern, see.

- Misprision - Mistake, error, misunderstanding.

- Perforce - Forcibly, violently.

- Ensue - Follow (logical outcome) Happen, become, befall.

- Remedy - Help, relief, alternative.

- Illusion - Deception, delusion, deceit.

- Knaveries - Roguish trickeries, trap.

- Hie - Hasten, hurry, speed.

- Welkin - Sky, heavens.

- Acheron - A river in hell.

- Leaden - Burdensome, heavy, cumbersome, dull.

- Virtuous - Powerful, fine qualities, praiseworthy, beneficial, arising from virtuous practice.

- Wont (Wonted) - Custom, habit, usual, accustomed.

- Derision - Criticize, laugh at someone or something in an insulting way.

- Fruitless - Barren, sterile, useless.

- Wend - Direct, betake.

○ ACT 4 SCENE 1

- Temples - The human body. (Church)

- Coronet - A small crown.

- Floweret - A small flower.

- Bower - Arbour, leafy glade or lady's chamber, a boudoir.

- Vexation - Agitation, disturbance, turmoil, torment, affliction, grief.

- Solemnly - Ceremoniously, with ritual celebration. 
- Prosperity - Success, good fortune.

- Jollity - Sexual pleasure, carnal enjoyment.

○ ACT 5 SCENE 1

- Blots - Slander, defile, blacken.

- Prodigious - Ominous, portentous, promising evil.

- Despised - Scorned, derided, treated with contempt.

- Nativity - Birth.

- Consecrate - Blessed, sanctified.

- Gait - Manner of walking, proceedings, doings.

Obviously, much of the analysis in a Shakespeare show is going to be driven by and derived from the text. The text is the bible, especially here in the world of Shakespeare where these characters say what they mean and mean what they say. The sub textual element is not nearly as typical as it is in realism. Shakespeare's characters leave it all out on the table. I am a firm believer in the idea that the character lives and dies only within the hours of the play.

Hence, the research and analysis can only come between Act 1 scene 1, and the final moment of the play. Everything I need to know and learn serves me from the words on the pages because after all that is the beautiful thing about being an actor: I have the ability to take black words on white pages (much like the ones you are reading right now) and turn them into a living, breathing person. I will delve further into that idea in the following pages describing my process. 


\section{That Will Ask Some Tears in the True Performing of It - Process}

Within this chapter, I will present an in depth look at my process from table work to performance. Interspersed in the section will also be excerpts from my personal journal. From day one, there are many ideas to take into consideration.

"Honestly, feeling pretty beat today. Frustrated on day one. Trying to put that away and focus. I already feel frustrated and anxious because there are 6,000 people in the cast, which is stressful, especially coming off of Seminar with only five people. I'm feeling nervous about my first time working with Jerry, my MFA acting mentor. Give a fuck level today: 4 . We discussed how it is important that everyone knows the whole play and what we're saying. There are not many cultural statements. The play stands for itself. It's like putting polka dots on a striped elephant, just let it be a striped elephant. Other ideas included: honor and accept the world of the play, comedy with magic, it's deeper than what people give it credit for, all the things that are happening to these people, and taking it seriously. We also addressed how to use things that will get our imagination going.

October 7, 2014”

Uta Hagen lends some helpful advice in Respect for Acting in the chapter titled, "First contact with the play." Her opening thoughts are as follows:

"When an actor first reads the play on which he is going to work, he is an audience. He visualizes the play and hears it like an audience. Whatever identification he may have with the play is similar to the identification an 
audience might have, and should not be confused with the organic identification he must find with the character he is going to play. He laughs at or with the play, he cries at or with the play, and, more than anything else, he cries and laughs at or with the character he is going to play. This is a normal reaction. At this point, he is the audience. He is still on the other side of the footlights; he is not yet on stage. This is why the images he conceives, and the tones and sounds he hears in his imagination on his first contact with the play must soon be discarded and not confused with the real work on the play and the part. The actor still has to go backstage and then evolve on stage."

In this vein, Hagen recognizes that in the early stages, I am not yet a part of the play. I need to evaluate the characters' actions and emotions. One way we do that is by sitting around a table for the first few days of rehearsal, and purely examining the play for what it is. We figure out the words, the actions and most importantly, the story. I think, in the early stages of the rehearsal process, it is important to accept the fantastical world of this play. Through my years of Meisner training under the tutelage of the same man who is directing this production, Professor Jerry McGonigle, we start by simply trusting the text and getting familiar with the words at face value. One thing we hold very dearly in the training here, and much like Uta reiterates above, we remove ourselves from any preconceived emotions and feelings. It is in similar fashion to the mechanical and working readings we tackle in the Meisner work. Mechanical readings, one of the most interesting techniques I have ever done, are essentially you and your scene partner saying your lines back and forth on exactly one monotonous pitch for the entire scene. It is quite robotic and "one note" to say the least. It really does hold weight and forces the actor to abandon any ideas one would have about how to say this line or how to deliver that line. We do that as 
performers; we are a narcissistic people, who upon picking up any given play at any given time and reading any given character's lines, immediately visualize ourselves playing the role and thus how we would go about screaming "Stella" at the top of our lungs or how we would shuffle on and bleed into, "Now is the winter of our discontent," in our most dramatic fashion. The working readings, as you might have guessed, are another step following those of the mechanical. You and your scene partner simply gather as many lines as you can memorize at once, and say them to each other while maintaining one hundred percent eye contact no matter what. Both of these exercises are very helpful to me in the early stages of being familiar with any words, from Shakespeare to Shepard.

"Coming in to another day of table work for the show, we are working our way through the script. We are analyzing the world and meaning of the play. Give a fuck level: 6. According to a handout from our dramaturge Dr. Jay Malarcher, we exist in a playground of the subconscious. Oberon comes from a frenchified version of the Germanic Albrecht or Alberich, being king of dwarves. Some more points tonight included: remember this is a dream, looking at the idea that Oberon and Titania are leaders of this fairy world and think of themselves as second only to Gods. It is also vital to remember that this argument is happening right now! The fairies describe things through a way of organic imagery.

October 9, 2015

Back to the rehearsal process; with all that being said, I was up against a tall task. The words are there to be learned, the images are there to be conjured, and the world to be explored. Focusing on all of these things was difficult at first; we had quite a large cast and quite a large 
range within the cast. There were freshmen all the way up to third year MFAs. Part of me felt confident, part of me felt nervous, and part of me felt a certain responsibility as the top class group within this rehearsal structure. I felt pressure to really be "good," whatever that means. Regardless, I knew this was a solid opportunity to lead by example, be it in memorizing lines quickly, in taking direction well, or supporting my part of the story to serve the rest of it.

My process is usually rather basic. I learn the lines, I write down my blocking, I review it before I go to bed every night, and I come in the next day to continually fine tune. My time and studies at West Virginia University lead me to explore through other methods and processes such as viewpoints, relaxation and visualization exercises, and most importantly, simplifying. These all came into play in Midsummer, especially within the magical world of the forest. I continually ask myself, what does this forest look like in my imagination? How does it feel? How does it sound? The director also reminded me, as Oberon, that this is my turf. I am the king of the inhabitants of this place. Through many moments of daydreaming and constantly returning to the text, the pictures of the environment become a bit more clear a day at a time.

Early on in the process many actors struggled with the rhyming meter of the text including myself. One thing the director said in one of the first days at the table really sticks with me: Let the images of the words carry the weight of the text not the rhyme. This is easier said than done; especially with many extended speeches and long-running monologues. One thing that keeps me out of the sing-songiness of the text is the punctuation. Finding the hard stops and the ends of thoughts keeps me free within the text. It is important to couple with that the idea of keeping it slow and simple in the early stages. I feel like many, especially with such heightened language, tend to gravitate toward a rapid pace with the words. It makes me think of all of those times in life where we read something and then once we look up from the book, we have 
absolutely zero comprehension of what we've just read. I use the term "we" loosely and mostly in reference to myself through most of grade school. But it's true, if I just blaze through the text, chances are I am not even really listening to the words that are coming out of my mouth. This leads me to some of the first rehearsals up on our feet, where most of mine were spent with Isaac Snyder (playing Puck) and Mya Brown (playing Titania).

"Coming into tonight, I am working with script out of my hands and starting to incorporate a rough physical life with different positions on stage. I still have no idea where I'm going with Oberon's physical life. Give a fuck level: 9. I'm working hard to make a lot of these moments "not so human" but still retaining an idea of royalty. The constant flow of thoughts must really flood constantly through my thought process.

October 19, 2014"

I definitely had some interesting dynamics with those two early on. I had worked with Mya before and have an immense amount of respect for her as an actor. I trust her on stage which really goes a long way. Mya makes me feel safe as an actor while simultaneously challenging me and giving me plenty to work off of. Isaac is a different story. He is young and somewhat inexperienced in comparison to myself and Mya. I had two completely different working relationships. I got frustrated in the first few rehearsals because there was a juxtaposition taking shape between the relationship with Mya and the one with Isaac.

When we rehearsed these scenes the first few times through, we read it once while sitting down then the director simply asks, "What are you saying?" Now Mya and I had a clear understanding for the most part of the scene and the language. We have been through many 
different scenarios of Shakespeare work before and have the individual chops to analyze it and break it down. Isaac, on the other hand, had not studied Shakespeare before which obviously is no fault of his own; he is just green. So many of our early rehearsals, and some later on, consisted of Mya and I getting a quick pat on the shoulder and a, "You good? Cool," from the director and then moving onto Isaac coaching him one line of text at a time.

At the same time, Isaac and I began to find some real chemistry and the rough outline of Puck and Oberon's relationship which is a difficult one to specify. On one level, they are as simple as a boss and an employee as Puck runs around doing Oberon's biddings throughout the course of a day. I struggled to not slip into the idea that the two of them are on the same level; getting caught up in the antics of the whole situation and to not make them some sort of Batman and Robin duo in such a borderline farcical world. While they can have elements of that at certain point, Oberon is in charge. I have a track record of playing the clown and being big and silly, but here it was a challenge to let that go and trust what is given, in the sense that stillness and power come into play with the language and dynamic. That is a huge jumping off point with all of my training here.

From day one, my teachers and mentors confronted me with many holes in my techniques as an actor. It has been three years of trust; trust what I'm doing, trust that what I'm doing is enough, and trust that I am interesting enough on stage just being me. I came in here with the idea that I need to comment on everything I am doing through my acting and choices on stage, and play this pseudo comedic and sarcastic quality. It has taken many classes and exercises to get to point of relaxation and confidence. Honestly, it is scary and quite terrifying to go on stage and simply be. It is an idea I never let myself immerse into in theatre jobs and even through my undergraduate training. Everyone says that as an actor, to go to those scary places, 
go to the dark places, and go to the places that frighten you to your core. Even in a comedy like Midsummer, I still have to go to the places of deep exploration to embody Oberon and get in touch with what is important to him. I have definitely had moments of that here, for which I am eternally grateful. It takes a tremendous amount of courage to do what we do as actors. My time here has forced me to confront that, not only in the class room, but in studio scene work and in the main stage productions as well. I got pushed around, I got railed, and I was broken down but then built back up. One of my professors here once told me that a master's program should not only change you as an actor, but it should also change you as a human being. Those words still, and will forever, ring true in my head.

With that in mind, that is why I chose to use Oberon as my point of focus here. He is not a clown, and does not need to be big and silly. He needs, nay, he requires, that stillness, focus and power, along with all of the trust in the world that I could give him. This leads me back into the early to middle points of the rehearsal process where it has become time to figure him out to his core.

I start, as always, simply. The director and I begin discussions of how this being moves and speaks. It is an amazing element to me as the actor to get to play with being a fairy, and the king of the fairies for that matter. We discussed how the fairies in the world of our play are not these Tinkerbell-like creatures that fly along ever so daintily. They are earthy, grimy and dirty.

From the first design presentation, it was evident that the costumes and make up would support these ideas. Puck and the other fairies are all in form fitting body suits that are a mixture of browns, yellows and oranges. The designs for both Oberon and Titania also followed suit on this idea, however on a grander scale. We have super stylized wigs heightened to the point that 
they look like horns. These wigs were indescribably frustrating at first and took several runs of the show to get accustomed to them. They were large, clunky and challenging to accept and incorporate into the idea of making them an extension of the body. The color palette remains the same with the addition of sweeping, layered capes. I

One of the biggest things that completed this entire feel was the fact that we were all bare-foot throughout the course of the play. So once we were in the space of the Gladys Davis theatre, walking into rehearsals was always followed by removing my shoes and socks. This makes a monumental difference in the way I feel connected to the world, and the soon to come set, which contains a larger than life tree with many climbable roots and bases. This led me to reflect back on some of the Laban work from my movement classes, specifically using the effort qualities as a way of getting into the skin of Oberon. I began using the tools from this movement method. These words provided imagery to help me figure out if and when Oberon is direct, indirect, quick, or slow.

The movement and physical vocabulary was something I definitely struggled with throughout this process. Fortunately, many different eyes come into the rehearsals here including vocal and movement coaches. Jessica Morgan Bishop, our resident movement professor, really opened my eyes with a lot of aspects of this character. I knew he was in power and in control, and I knew he would work in contrast physically to someone like Puck. Physically, I started to draw from Laban effort qualities such as the difference between glide and float, for example. These qualities differ in the forms of indirect and direct movements as well as duration; sustained and quick. These qualities were a big part of locking in Oberon's mobile vernacular as well as how he owned the space. Once I started exploring these Laban qualities, I obtained a clearer idea of the character, and I started trusting that my stillness and direct power worked in 
contrast to the scattered nature of the other fairies and Puck. This took me a while to develop but helped me to manage my movement in the midst of the scenes.

"Today was a drastic difference in some of the stuff in my first few scenes. I'm getting good tension and fuel with Mya on stage. The chemistry is building and the sense of the marital spat is really growing. I'm playing with a lower pitch, down an octave or two from my normal speaking voice. We discussed how we should always be on our text and driving the words forward. Give a fuck level: 8 .

October 28, 2014"

The Laban work also affected Oberon's vocal qualities and deliveries to the other characters. Jerry also spoke with me about how his voice was one of deep chest resonance. We worked over the course of the middle part of the rehearsal process in specifying this sense of the power that came from a lower vocal range and filled the entire space as to mirror the strong and specific movement, motions and stage life. I worked diligently on this and tried to find exactly where all of these techniques tied together which was indescribably frustrating at times due to the fantastical nature of the world and how to make sense of it coherently.

Inching closer and closer to tech and opening, we begin running long chunks of the play, which is always so refreshing in the sense of getting a flow of the story. It gives me so many opportunities to string thoughts and ideas together. I find myself really getting on a roll with Mya and Isaac as we continue to sharpen relationships and moments.

One thing I continue to struggle with is using the introductory scene as a starting point to drive my actions. It is such a simple thing that Oberon wants, not getting the changeling child, that is. In theory, it drives the jealousy and revenge, which I understand, but it doesn't strike me 
as important enough for some reason. In his book Theatre, David Mamet touches on this by saying, "We may note that the actor who 'just doesn't like his objective anymore' is not unlike the newly married man who has fallen out of love with his wife. The two share this: their new perception is fostered by fear - by the fear of that intimacy which has been brought to life by commitment." So I begin to feel this "fear" of not having a strong enough point of view, upon where I turn to Jerry, who promptly instructs me to keep simplifying and trusting that the text has given me enough to draw from and that simplicity will endure to drive me to what I am after. I instill my faith and blindly follow. I listen to the words of Walt Whitman and his poem Pioneers! O Pioneers! (which is also tattooed on my left shoulder) "For we cannot tarry here, We must march my darlings, we must bear the brunt of danger, We, the youthful sinewy races, all the rest on us depend, Pioneers! O Pioneers!"

As it always does, tech weekend rears its ugly head. This is a bear of a show to put through the tech ringer. There are the normal aspects with lighting, sound and timing. But also, the element of the gigantic tree (which I climb up and down) and the larger-than-life costumes and wigs come into play as well.

"Today was a lot to deal with. The costume, make up and wig are just too much to deal with. I had so much make up on and I thought, as I looked in the mirror, that I looked like a fucking Marx brother. However, I think it is going to be scaled back, which I like. But I still feel like I am lacking confidence or understanding in the wig, like Syndrome from The Incredibles. The next few nights will definitely be adjusting to that.

November 16, 2014 
The costume and wig were quite awkward and hard to get used to at first, but it really helped me in tying a lot of the characteristic of Oberon together. It really did complete his look and feel and mirrored what I felt on the inside to how he is seen on the outside. Having all of the elements together finally put me in a comfortable place and gave me some confidence that I had been missing through some of this process. The other side of this double-edged sword known as tech week is keeping all of the "acting" intact. More often than not, acting gets put on the back burner for tech weekend and the focus shifts on the timing of implementing the lights, sound, scene changes, etc. Also, all of the work in rehearsals can sometimes get hindered by the hundreds of sudden technical changes, i.e. climbing up a massive tree, Titania floating fifteen feet in the air, having a cape, and dealing with props in near darkness. Boy did I not do well with those flowers for quite a while. With all of this driving us closer to opening, it is crucial that I trust my Meisner training to this point and all the work that we have put into where we are in the process. Because after all, "The foundation of acting is the reality of doing." (Meisner, 16) 


\section{Pray You; For Your Play Needs No Excuse - Performance and Evaluation}

"Invent nothing, deny nothing, speak up, stand up, stay out of school." (Mamet, 16) In these words of David Mamet, I relate (mostly to the first four) the ultimate job as the actor in the performance realm of the process. To me, it is in the direction of being on stage and not forcing anything to happen, while at the same time, accepting everything that will inevitably happen during any given moment on stage. What else could be truer?

I found much enjoyment during the run of this production. We had the added bonus of doing it several more times for high school and middle school matinee audiences. I was blown away when one of our best audiences was the middle school crowd. At first glance I thought, what sense does that make? But then upon thinking on it, it makes total sense and was actually quite motivating. Shakespeare's themes and motifs are so universal and simple that they can really be picked up on by anyone with a willing ear, even 200 twelve year olds in north central West Virginia. I enforced the values that we put into the story from day one from the basic stepping stones that string the story together.

Throughout the course of the run, I continued to discover more and more, especially being in front of an audience which every comedy needs because of the pace and timing. It dawned on me in this show that while I knew Midsummer was funny and nonstop, the audience becomes your last scene partner, literally and metaphysically. The attention, laughter and tears of the audience become a result of product and living truthfully. But also, in this world of theatre and the moments of soliloquy, the audience members are literally the ones listening to you, and they are the ones who you are asking for help. In the several moments I had of speaking directly 
to the audience, I never knew what exactly I was going to get from them. So naturally, I have to hammer the eternal Meisner question: how are they behaving?

I had two moments that really stood out to me while speaking directly to the audience. The first was three performances into the run. It took place following the end of the four lovers (Lysander, Helena, Demetrius and Hermia) and their "cat fight" scene in Act three. What had happened in the two previous performances was a roar of applause after they finished the scene which was appropriate. It is a long-winded scene and the lovers do a phenomenal job. Now, in this performance, the scene ended, and a few people in the audience started to clap, and by few I mean only five or six. The rest of the crowd wasn't sure if it was okay or the right time, so in very Globe-like fashion, I completely dropped my physicality and held up my hands and encouraged them to clap which conjured a huge response and the crowd erupted into laughter and applause. Immediately following I snapped back down to my death grip over Puck.

The second was during the second week of the run. At the top of our Act two, I entered through the down stage left vom and began the act with, "I wonder if Titania be awaked..." (McDonald, 41) I came in and scared the living day light out of this young lass who was texting. She gathers her composure and yet continues to text, to which I respond by simply standing there staring at her and begin to mock her by doing so myself. In retrospect, I should have taken it from her and tossed it into the tree on stage.

I learned so much in this show and the run of it. I learned how it can change and adapt on any given night. I learned the story more and more each night. I learned a lot about myself and how my training here has culminated into being strong and confident, trusting and still, and 
malleable and truthful on stage. I get lost in the world, in the imaginary circumstances, and let the stakes and what's important drive me through the action.

It is honestly amazing, the things that can be found in any moment throughout the course of the performance. From very early on in our actor training, we are told not to go out every night and repeat something that happened last night, or last Friday, or that one time in dress rehearsal. We are told not to go on "auto pilot" and not to make anything that happens a habit. Every moment is new. Every scene is alive and happening right now. Every night stands alone and none of this has ever happened before. After ten o' clock, the world doesn't exist and Oberon is dead until he is reborn tomorrow at seven thirty.

"Your life in the theater, like mine, will pass before you are aware of it. And you will realize why the old folks reminisce-it is not that they are nostalgic; they are stunned. It went so quickly. We all would like to be a part of, to create, that theater which we would participate in with pride. On which we could reflect with pride. To do so, one has to buy a ticket. The price of admission is choice-the choice to participate in the low, the uncertain, the unproved, the unheralded, to bring the truth of yourself to the stage. Not the groomed, sure, talented, approved person you are portraying; not the researched, corseted, paint-by-numbers presentation-without-flaws, not the great actor, but your self-as uncertain, as unprepared, as confused as any of us are. Art does not flourish in subsidy, and it does not flourish in the studio, it is more frightening, more sorted, funnier, and truer than the certainties of the instructor. It is the stuff of the soul. It is the counterbalance to the reasonable view of the world; and, so, it is likely to be 
despised. To cherish, rather than despise it-that's the job of the artist." (Mamet, 123-124)

All in all, what I can gather from this entire experience was trust in my work and what I knew how to do. I trusted simplicity and I trusted the text in a grand culmination of my efforts throughout the process. Guess what: it paid off. 


\section{Works Cited}

- McDonald, Russ, ed. A Midsummer Night's Dream. The Pelican Shakespeare ed. New York City: Penguin Books, 2000. N. pag. Print.

- Crystal, David, and Ben Crystal. Shakespeare's Words A Glossary \& Language Companion. New York City: Penguin Books, 2002. Print.

- Stanislavski, Constantine. An Actor Prepares. New York City: Routledge/Theatre Arts Books, 1989. Print.

- Hagen, Uta. Respect For Acting. New York City: Macmillan Publishing Co., Inc., 1973. Print.

- Mamet, David. True and False Heresy and Common Sense for the Actor. New York City: Vintage Books, 1997. Print.

- Mamet, David. Theatre. New York City: Faber and Faber Inc., 2010. Print.

- Meisner, Sandford. On Acting. New York City: Vintage Books, 1987. Print.

- Whitman, Walt. "Pioneers! O Pioneers! in Leaves of Grass." columbia.edu. N.p., n.d. Web. 28 Mar. 2015 